\title{
Cancer Burden in Nigeria; Possibility of a New Hope in a New Political Dispensation
}

\author{
Aisagbonhi Henry Osaro ${ }^{1 *}$, Daniel Olusoji James ${ }^{2}$, Esther Ametor Ajakaiye A ${ }^{3}$, Odega \\ Kelvin Ifechukwude ${ }^{4}$, Udo Iniobong Anselem ${ }^{5}$ \\ ${ }^{1}$ Olabisi Onobanjo University Teaching Hospital, Sagamu. Laboratory Services Department \\ Ogun State, Nigeria \\ ${ }^{2}$ Olabisi Onobanjo University Teaching Hospital, Sagamu. Department of Community \\ Medicine and Primary Care, Nigeria \\ ${ }^{3}$ Department of Physiology, University of Ibadan, Ibadan. Physiology Department Oyo State. \\ Nigeria \\ ${ }^{4}$ University of Benin Teaching Hospital, Anatomical Pathology Department. Edo State, \\ Nigeria \\ ${ }^{5}$ Babcock University Teaching Hospital, Cardiac Center. Ilishan. Ogun State, Nigeria
}

\begin{abstract}
Nigeria looks forward to the emergence of another political dispensation. National elections are soon to take place with resultant political changes in ministerial leadership positions across the nation at federal, state, and local government levels' including the ministry of health; however, in this article, the concern was with the general health care in Nigeria and with a focus on the prevailing situation of Cancer health care in Nigeria. Statistics showed that there is a rising global cancer epidemic in Nigeria. The level of Cancer incidence and mortality counts in Nigeria as of 2012 and still counting' was severely high amongst women- 64709 (63\%) and 40647(57\%) compared to men $37370(36.6 \%)$ and 30924(43\%), respectively. The emergence of a new political dispensation in 2023 ushers in a possibility and awakening of new hope in general health care. Therefore, this article highlighted the observed challenges and proffered solutions for the purpose of informed decisions. Based on staff and patient perspective interviews and discussion, the following major aspects, including a critical review of health governing boards, administration, technology, specialty expansion via partnership, quality assurance, health funding, were identified, addressed and solutions proffered.
\end{abstract}

Keywords: Challenges, Epidemic, Informed Decisions, Ministry of Health, Cancer, Political Dispensation, Proffered Solutions, Patient Satisfaction.

\section{Introduction}

Nigeria as a nation is looking forward to the emergence of another political dispensation. National elections are soon to take place with resultant sporadical changes in both political and ministerial leadership positions across the nation at federal, state, and local government levels. As observed in most past transitions, it is the choice of the incoming government to either maintain continuity of initial government policy implementations or abandon them for personal or political party initiated new ideas regardless of the wholesome impact in terms of finance and economic cost. The same applies to all ministries; However, in this article, the concern is with the general health care in Nigeria and with a focus on the prevailing situation of Cancer health care in Nigeria and possible interventions by the new government. There is 
a rising global cancer epidemic in Africa [1], but why is the epidemic constantly prevalent with a high mortality rate and low survival rate in developing nations like Nigeria, and what can professionally be done to change the present-day paradigm?

The emergence of a new politic dispensation in 2023 ushers in a possibility and awakening of a new hope in general health care and a focus on the delivery of Cancer health care in Nigeria. This article hopes to highlight the observed challenges and proffer solutions to the expected government.

Nigeria is a country in West Africa with a coast on the Gulf of Guinea and the Atlantic Ocean. Her geography runs from southern coastal swamps to tropical forests, woodlands, grasslands, and semi-desert in the north. There are 36 states, and with approximate 184 million inhabitants accounting for $47 \%$ of West Africa's populations and a population growth rate at $2.5 \%$ and an average life expectancy of 54 years [2], Oil provides $90 \%$ of the country's exports and about $75 \%$ of the government's revenues. The fifth consecutive national election held in 2015 marked the first time in Nigeria's history that it saw a peaceful transfer of power between two political parties.

The current administration, led by President Muhammadu Buhari, identifies fighting corruption, increasing security, tackling unemployment, diversifying the economy, enhancing climate resilience, and boosting the living standards of Nigerians as main policy priorities [2]. However, health is not one of them. The president and the majority of political figures has had recourse on various occasions to seek health treatment in the UK [3, 4].

Activities in the Nigerian health and social work sector contributed only $0.65 \%$ of Nigerian Gross Domestic Product (GDP) in 2013, up from $0.61 \%$ in 2010 based on the rebased GDP basis. It is estimated that consumption of healthcare goods in Nigeria will grow by a Compound Annual Growth Rate of $16.2 \%$, from USD9 billion in 2013 to USD111 in 2030 [5]. Nigeria has one of the largest stocks of human resources for health $(\mathrm{HRH})$ in Africa but, like the other 57 HRH crisis countries, has densities of Nurses, Midwives, Pharmacist, Scientists, and Doctors that are still too low to deliver essential health services (1.95 per $1,000)$ effectively. In recent years migration to foreign countries has declined, and the primary challenge for Nigeria is inadequate production and inequitable distribution of health workers [6]. The health workforce is concentrated in urban tertiary health care services delivery in the southern part of the country, particularly in Lagos [7].

Nigeria has 13 cancer registries; however, most of these cancer registries data are not routinely collected and published due to lack of adequate funding and electronic data management. The absence of this information on incidence, prevalence, pattern, and high-risk factors, as seen in Nigeria and other developing countries, have essentially hindered the determination of the level of occurrence and pattern of distribution of the different cancer types, which will aid successful planning, implementing, and evaluating the control of cancer. [8-10], The National Human Resources for Health forum steering committee is saddled with the essential role of policy drive and implementation of the nation's health. It comprises of members from the following stake holder's groups [11]. Federal Ministry of Health; Education; Finance; Labour.

1. Federal Civil Service Commission.

2. Manpower Development Division/Office of the Head of Civil Service of the Federation, National Universities Commission (NUC).

3. Tertiary Hospital Service Commission.

4. National Primary Health Care Development Authority.

5. Representatives from Registration Bodies.

6. Representatives from Professional Bodies.

7. Representatives of bilateral agencies.

8. Representatives of Non-governmental Organizations. 
9. Representatives of the private for-profit sector.

Considering the words of a twenty-two-yearold cancer patient Saadatu Usman at the National Hospital in Abuja, "I have a dream to get up, to get out of this sickness, to be what I'm destined to be. I am a graduate, but I can't work, she says. "I am running around, searching for money, looking for help. Unless more cash can be found for a new treatment, she may have only months to live [12], and even when she manages to get the money, access to therapy may be another challenge. Cancer is not a death sentence, but in Nigeria, the prevalent statistics depict otherwise.

The cancer burden in Nigeria has become a prevailing nightmare which is fast having a disastrous impact on the health and financial economy. It is a disease where malignant cells grow out of control and invade, erode, and destroy normal tissue. Malignant cells invade neighbouring tissues, enter blood levels, and metastasize to the different sites $[13,14,15]$. It is a group of over a hundred different diseases of which each disease has their own set of risk factors [16]. It's a generic term for a large group of diseases that can affect any part of the body. Other terms used are malignant tumours and neoplasms. One defining feature of cancer is the rapid creation of abnormal cells that grow beyond their usual boundaries and which can then invade adjoining parts of the body and spread to other organs; the latter process is referred to as metastasizing. Metastases are a major cause of death from cancer [17].

WHO reported that about 24.6 million people live with cancer worldwide, and $12.5 \%$ of all deaths are attributable to cancer, and if the trend continues, as estimated, about 16 million cases was diagnosed in 2020, of which about $70 \%$ was in Africa following exposure rate, poverty, and social and economic determinants? There are majorly 2 types of cancer cells: benign tumor cells and malignant tumor cells. Benign means "not cancer".
Benign tumor cells grow only locally and cannot spread by the invasion of metastasis.

Malignant means "cancer". Malignant cells invade neighbouring tissues, enter blood vessels, and metastasize to different sites of the body. Cancer arises from the transformation of normal cells into tumour cells in a multistage process that generally progresses from a precancerous lesion to a malignant tumour. These changes are the result of the interaction between a person's genetic factors and external agents within the environment. Categories of external agents include physical carcinogens, such as ultraviolet and ionizing radiation; chemical carcinogens, such as asbestos, components of tobacco smoke, aflatoxin (a food contaminant), and arsenic (a drinking water contaminant); and biological carcinogens, such as infections from certain viruses, bacteria, or parasites [17]. The causes are broadly environmental factors and genetic.

The environmental cause of cancer includes Alcohol, Tobacco, Dietary factors, Hormones, Radiation from occupational exposures, viruses, parasites or bacteria, Some chemicals, customs, habit and lifestyles, sunlight, pollution, and drugs. Examples of Genetic causes include heredity cases such as Retinoblastoma in children and leukaemia in Mongols.

Aging is another fundamental factor for the development of cancer. The incidence of cancer rises dramatically with age, most likely due to a build-up of markers for specific cancers that increase with age. The overall risk accumulation is combined with the tendency for cellular repair mechanisms to be less effective as a person grows older.

The risk of developing cancer increases with age. It is associated with risk factors such as gender, race, personal and family medical history, including long term use of oral contraceptive pills, early age at first sexual intercourse, early age at first birth multiparity, multiple unfaithful male sexual partners, smoking, immune suppression, and alcohol [18]. 
Other risk factors are largely related to lifestyle choices, while certain infections with human papilloma viruses (HPV) enhance exposure.

Certain vitamin deficiencies and hormonal factors are also possible risk factors. Occupational exposures and some environmental factors can also be related to developing cancer.

The risk factors for cervical cancer, commonly known by the public according to [19], includes early initiation of sex, multiple sex partners, multiple births, vaginal douching, cigarette smoking, recurrent STDs, and excess alcohol drinking.

Some chronic infections are risk factors for cancer and have major relevance in low- and middle-income countries. Approximately 15\% of cancers diagnosed in 2012 were attributed to carcinogenic infections, including Helicobacter pylori, Human papillomavirus (HPV), Hepatitis $\mathrm{B}$ virus, Hepatitis $\mathrm{C}$ virus, and Epstein-Barr virus. Hepatitis $B$ and $C$ virus and some types of HPV increase the risk for liver and cervical cancer, respectively. Infection with HIV substantially increases the risk of cancers such as cervical cancer [20]. In Diagnosis of Cancer, usually, if one has symptoms of cancer or the screening test results suggest cancer, it is appropriate to find out the cause as it could be cancer or other causes. The history of the patient is required as well as a physical exam. Other laboratory test scans and procedures are usually planned.

\section{Laboratory Test}

A concentration of high or low levels of certain substances in one's body can be a feature of cancer. Therefore, laboratory tests of patients' body specimens- blood, urine, faces, or other body fluids can assist in accurate diagnosis. Laboratory tests are an important tool but cannot be entirely relied upon alone to diagnose cancer. Imaging Procedures creates pictures of areas inside your body that help the physician see if there is a tumour via.

\section{CT Scan}

An x-ray machine linked to a computer takes a series of detailed pictures of your organs. You may receive a dye or other contrast material to highlight areas inside the body. Contrast material helps make these pictures easier to read.

\section{Nuclear Scan}

For this scan, you receive an injection of a small amount of radioactive material, which is sometimes called a tracer. It flows through your bloodstream and collects in certain bones or organs. A machine called a scanner detects and measures radioactivity.

The scanner creates pictures of bones or organs on a computer screen or on film. Your body gets rid of the radioactive substance quickly. This type of scan may also be called a radionuclide scan.

\section{Ultrasound}

An ultrasound device sends out sound waves that people cannot hear. The waves bounce off tissues inside your body like an echo. A computer uses these echoes to create a picture of areas inside your body. This picture is called a sonogram.

\section{MRI}

A strong magnet linked to a computer is used to make detailed pictures of areas in your body. Your doctor can view these pictures on a monitor and print them on film.

\section{PET Scan}

For this scan, you receive an injection of a tracer. Then, a machine makes 3-D Pictures that show where the tracer collects in the body. These scans show how Organs and tissues are working.

\section{X-rays}

X-rays use low doses of radiation to create pictures of the inside of your body. 


\section{Biopsy}

In most cases, Doctors need to do a biopsy to make a diagnosis of cancer. A biopsy is a procedure in which the doctor removes a sample of tissue. A pathologist then looks at the tissue under a microscope to see if it is cancer. The sample may be removed in several ways: With a needle: The Doctor uses a needle to withdraw tissue or fluid. With an endoscope: The Doctor looks at areas inside the body using a thin, lighted tube called an endoscope. The scope is inserted through a natural opening, such as the mouth. Then, the doctor uses a special tool to remove tissue or cells through the tube.

\section{Surgery}

Surgery may be excisional or incisional. In an excisional biopsy, the surgeon removes the entire tumor. Often some of the normal tissue around the tumor also is removed. In an incisional biopsy, the surgeon removes just part of the tumor (National cancer institute, 2012).

\section{Factors Contributing to Global Causes of Cancer}

The global causes of cancer include Hormones at the rate of $18-20 \%$, smoking and alcohol use which accounts for $30 \%$ of cancer, while chronic infections and unbalanced diets accounted for $18-20 \%$ and $30-35 \%$ of cancer, respectively. Others include occupation and pollution.

The sign and symptoms include Early cancer with no symptoms, change in bowel habits or bladder functions, Sores that do not heal, unusual bleeding or discharge, Lumps or thickening of the breast or other parts of the body, Indigestion or difficulty swallowing, recent change in wart or mole and Persistent coughing or hoarseness.

Types of Cancer with brief description of localization; some common carcinoma includeLung cancer, Breast cancer, Cervical cancer, Colon and rectal cancer, Endometrial cancer, Pancreatic cancer, kidney cancer, Prostate cancer, and Thyroid cancer. Others include Skin cancer, Leukaemia (Bloodstream), and Lymphomas (Lymph node), etc. Cancer is diagnosed via the following ways.

1. Screening.

2. Self-examinations.

3. Biopsy.

4. X-rays, CT scans, MRI scans, PET scans, and ultrasound scans.

5. Molecular diagnostic test.

The treatment of cancer includes:

1. Cancer Surgery.

2. Radiotherapy.

3. Chemotherapy.

4. Immunotherapy.

5. Hormone therapy.

6. Gene therapy.

7. Cancer-specific immune system cells to treat cancer.

\section{Materials and Methods}

A retrospective descriptive study on critical related analysis of the burden of cancer and its distribution pattern in Nigeria was performed using data used from the report by [21] and two international studies [22, 23].

Further Patient perspective was obtained on the subject matter via oral interview and discussion with a few senior oncology staff and educated patients of a private hospital in Lagos, Nigeria.

The incidence of cancer cases in the world was estimated at around 12,667,500, while in West Africa, there are about 184,100 new cases per annum. South-Central Asia accounted for the highest number of new cases in 2008 at $1,423,100$ [24].

According to the American cancer society in 2013 [25], Prostate Cancer accounted for the highest number of new cases (28\%) while Pancreatic cancer accounted for the lowest new cases $(3 \%)$ in the Male category. Similarly, amongst the female, Breast Cancer accounted for the highest number of new cases (29\%), while ovarian cancer accounted for the lowest new cases $(3 \%)$. Infection and Diet accounted 
for the major causes of cancer in developing countries compared to the developed countries.

Off the Staggering statistics in West Africa, the burden of cancer in Nigeria has remained prevalent compared to other parts of West Africa. The earliest study from Nigeria was from the Ibadan Cancer Registry-196069(ICR); Edington \& MacLean reported higher rates of cancer in females with age-standardized rates (ASR) of 105.1 and 78 per 100,000 females and males, respectively [26].

In 1998, 74.5 per 100,000 females and 63.9 for males was recorded from the same centre. In Zaria, 1976-78 data reported 1575 cases with $52 \%$ of cases in males and $48 \%$ in females; the latter study, however, showed more cancers in females than males. [27, 28]. The complete burden of cancer in Nigeria is unknown, and this is mainly due to lack of statistics or underreporting; however, this is not peculiar to Nigeria but most parts of Africa. Prior to 2009, in a study of cancer registry literature update from all over the world, only $1 \%$ of the literature emanated from Africa compared to $34 \%$ and $42 \%$ from Europe and Asia, respectively [28], Although there are 13 cancer registries located in various tertiary hospitals in various parts of Nigeria, however, most of the Registries are poorly funded as they all produce hospital-based data except probably the Ibadan and Zaira Cancer Registry. The registries include:

1. The Ibadan Cancer Registry, University College Hospital, Ibadan.

2. Cancer Registry, Lagos University Teaching Hospital, Lagos.

3. Cancer Registry, Jos University Teaching Hospital, Jos.

4. Cancer Registry, Ahmadu Bello University Teaching Hospital, Zaria.

5. Ife/Ijesha Cancer Registry, Obafemi Awolowo Teaching Hospital Complex, IleIfe.

6. Cancer Registry, University of Nigeria Teaching Hospital, Enugu.
7. The Cancer Registry, University of Ilorin Teaching Hospital, Ilorin.

8. Cancer Registry, University of Maiduguri Teaching Hospital, Maiduguri.

9. Cancer Registry, University of Benin Teaching Hospital, Benin City.

10. Cancer Registry, Aminu Kano University Teaching Hospital, Kano.

11. Cancer Registry, Nnamdi Azikwe University Teaching Hospital, Nnewi.

12. Cancer Registry, University of Calabar Teaching Hospital, Calabar.

13. Cancer Registry, Usman Danfodio University Teaching Hospital, Sokoto.

\section{Cancer Scenario in Nigeria}

In 2002, WHO estimation of cancer incidence from all sites in 2002 for Nigeria was 90.7 and 100.9 per 100,000 for male and female respectively, while the mortality rates were 72.2 and 76 respectively [29], but currently in the Globocan 2012 report, WHO estimated cancer incidence in Nigeria revealed a decline in incidence rates-79 and 129 per 100,000 for male and female respectively while the mortality rate declined to 67.4 per 100,000 for male and female rose to 78 per 100,000 [23].

The burden of cancer is increasingly growing, and it is a leading cause of death worldwide [8]. There are over 100 types of cancer, and their symptoms vary widely [16].

Deaths from cancer in the world are projected to continue to rise, with an estimated 11.4 million in 2030 [30, 31]. The burden of cancer is increasingly appreciable in Nigeria, and the world health organization reported that there are about 100,000 new cancer cases in the country each year; however, it is believed that based on observations, the figures would sporadically rise as high as above 100,000 new cases annually as at 2010 [28].

The level of occurrence and pattern of distribution of different cancer types in two functional cancer registries in south-western Nigeria was reported in an article titled "cancer distribution pattern in south-western Nigeria." 
[21]. A total of 5094 cancer patients were registered between 2005-2009 in both Lagos $(60 \%)$ and Ibadan (94\%) registries [21]. Breast cancer (20\%) accounted for the majority of the total types of cancer cases in the entire data from the south-western region.

Breast Cancer $(29.3 \%)$, Cervical cancer (12.3\%), Fibroid (6.9\%), ductal (4.9\%), and ovary $(4.7 \%)$ were predominant in females while Prostate (9.4\%), Liver cancer $(8.1 \%)$ were predominant in males within the southwestern region only, however, the Globocan 2012 incidence data report by the international agency on research on cancer and the World Health Organization gives a detailed cancer incidence and mortality data in Nigeria, based on regional data rate. Following the abysmal statistics of cancer data in Nigeria, it is difficult to obtain complete national data within a centre in Nigeria. However, the world health organization, via the international agency for research on cancer, obtained detailed cancer data with quality of regional data sources. Table1a and $1 \mathrm{~b}$ show the complete data on recent cancer incidence and mortality in Nigeria. 


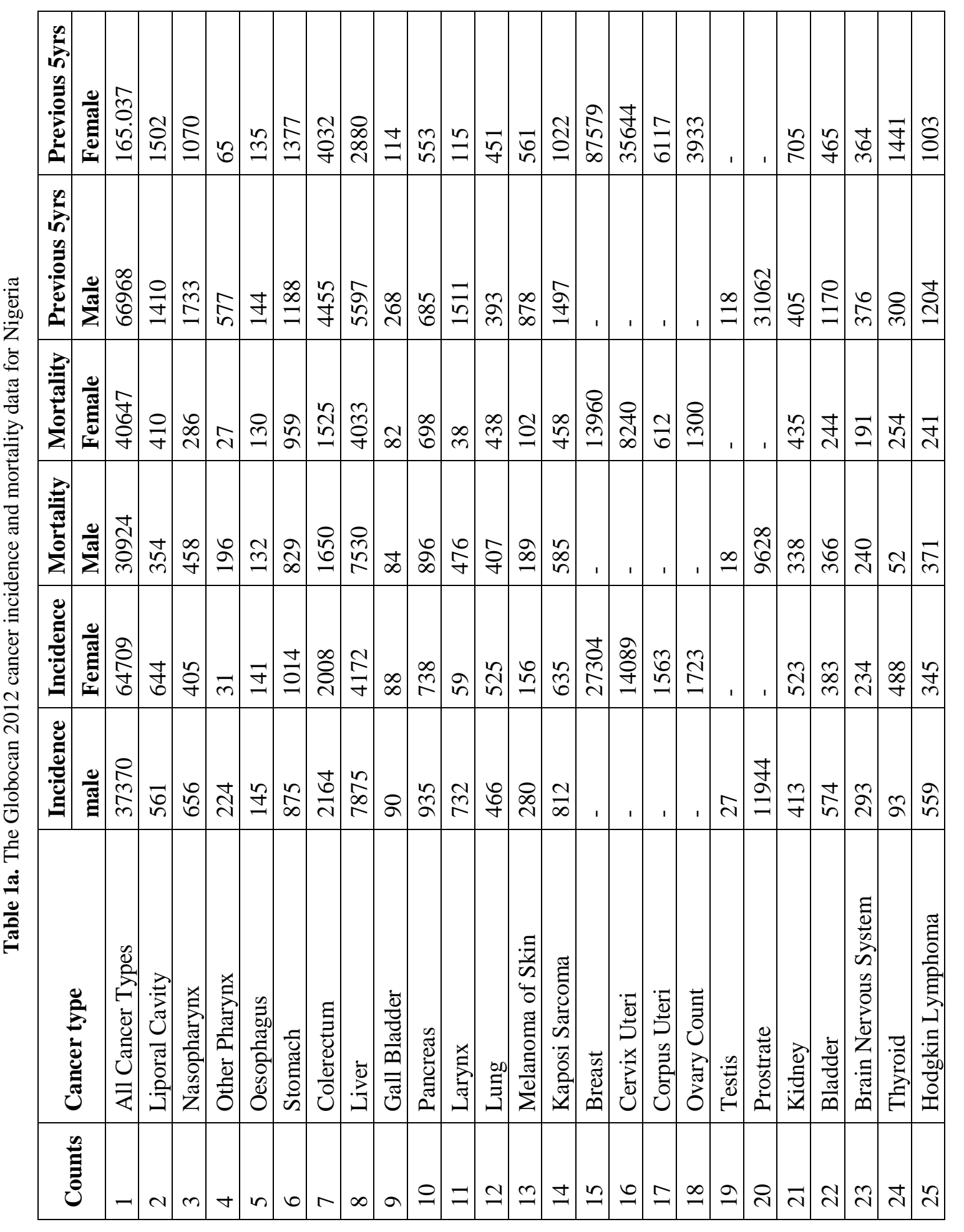




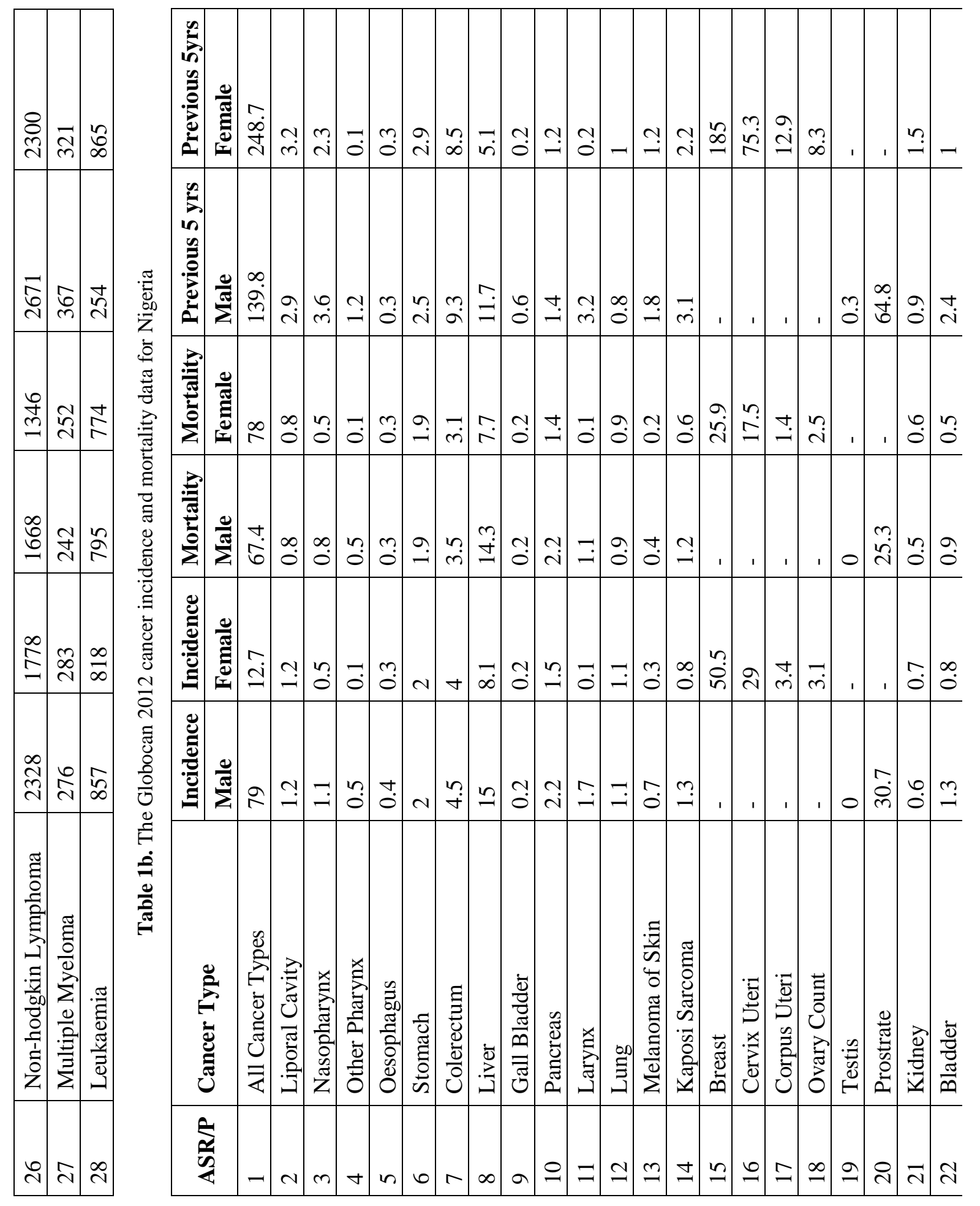




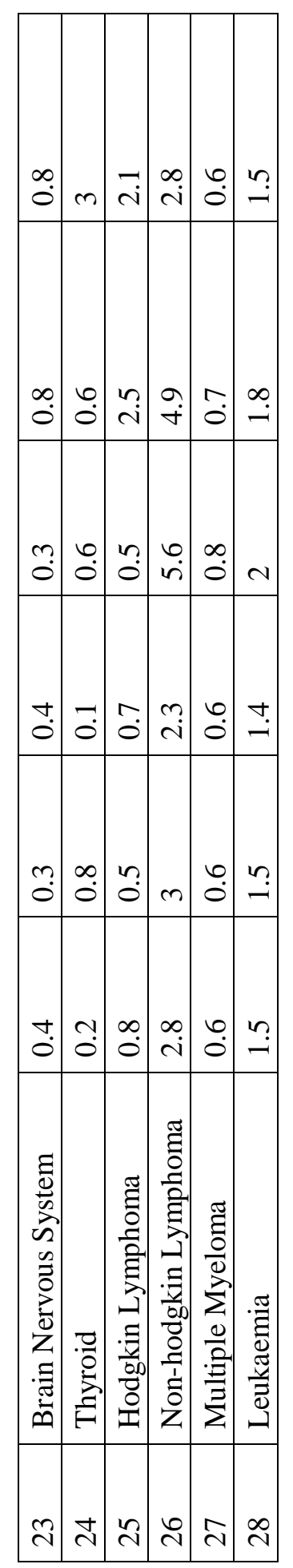


The rate of incidence in male and female as well as the mortality rate in both sexes was reported. The previous data for 5 years for both sexes was reported as well. In 2012, the total incidence of cancer in males In Nigeria was 37,370 (36.6\%), while within the previous 5 years, the total data was 66,968 (28.8\%).

Similarly, the total incidence of cancer in females in Nigeria was 64,709(63\%) in 2012, while the previous 5yrs, the total data was 165,037 (72.8\%). Following the frequency of cancer incidence in males according to cancer types as seen in Table 1, prostate cancer $11,944(36 \%)$ accounts for the highest incidence of cancer amongst males followed by the liver - 7,875 (23.7\%), non-Hodgkin lymphoma - 2,328(7\%) and colorectum cancer$2164(6.5 \%)$.
The least incidence of cancer types in females includes another pharynx $-31(0.05 \%)$, while in males, the least incidence of cancer type is testis-27(0.08\%).

In the frequency of cancer mortality due to cancer types, Breast cancer - 13960 (37.6\%) accounts for the highest cause of female mortality in Nigeria. Similarly, prostate cancer 9628(35.0\%) accounts for the highest mortality amongst males in Nigeria. In Table 1a and Figure 2, the level of Cancer incidence and mortality counts in Nigeria is severely high amongst women - 64709 (63\%) and 40647 (57\%) compared to men -37370 (36.6\%) and 30924 (43\%), respectively.

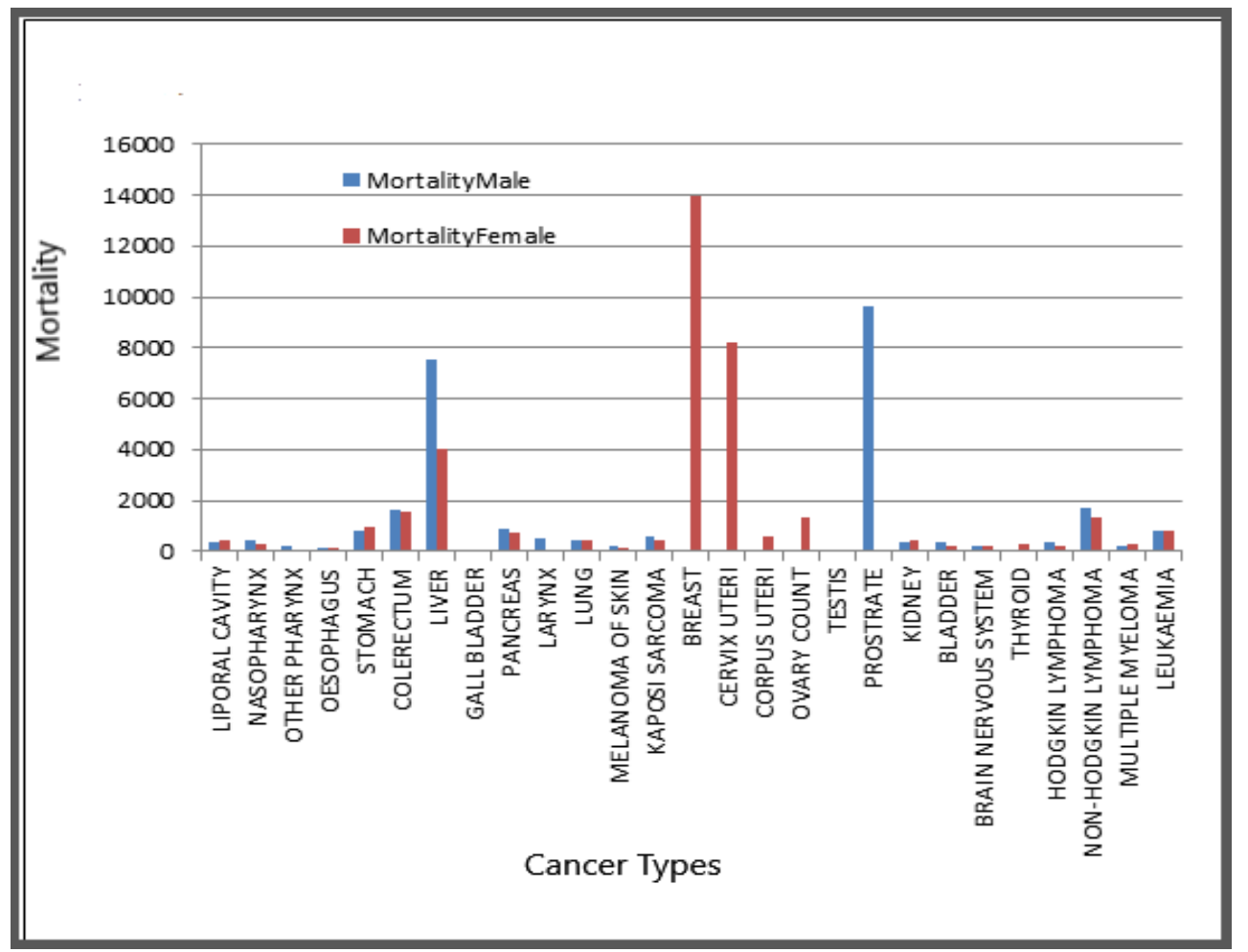

Figure 1. Comparison of Cancer Mortality in Nigeria between Male and Female

These mortality rates are threatening and alarming; about 500 women die monthly of cancer in Nigeria. Most of the patients die due to lack of access to treatment coupled with consequent bad management. The present situation be-deviling the cancer healthcare in Nigeria is much more a catalyst to enhancing the worsening figures. Generally, the challenges stem from the inequity within the health sector. This inequity has been attributed to:

1. Lack of public and private sector coordination.

2. Favouring indigenous hires. 
3. Commercial pressures in the private sector that lead to poor quality work.

4. Work environments that contribute to low motivation.

5. Less-than optimal productivity, high attrition - especially from rural areas, and,

6. Lack of planning based on staffing projection needs' resulting in an overproduction of some categories of health workers and a lack of others [32].

These challenges are further compounded by the fact that the federal government accepts and regulates 3 systems of health care delivery: orthodox, alternative, and traditional. The absence of a common HRH and data collection system also led to a lack of coordination in collecting $\mathrm{HRH}$ information, which resulted into various stakeholders getting fragmented information.

With a focus on Cancer health care delivery in Nigeria, much work needs to be done by the incoming health representatives at all levels of governance. Some of the major aspects for possible review include the level of infrastructure, manpower resources, and financing. I am proposing a state of emergency in the health sector with proportional attention to overhaul the cancer delivery health care system In Nigeria.

Qualitative health care is a fundamental right of all citizens of any given country. The Nigerian health care delivery can be broadly classified into two. They include the existing traditional medicine and the modern orthodox medicine, which came to our shores with the arrival of the European colonialists [33, 34]. This reveals that the Nigerian Governments have shown much commitment in improving quality health care in health institutions in the past. However, the level of implementation and progress has been slow. The challenges and attitudinal unresponsiveness have been major barrier. The case is the same with Cancer health care in Nigeria as well.

Quality improvements have become a matter of urgency in most nations. Beyond the health sector, demand for quality improvement cuts across a vast sector of the global economies. It is a crucial process that is realizable but on the strength of a strong, democratic, and sound leadership. To achieve quality improvement in the health sector, every bureaucrat, stakeholder, interest group, and front row personnel are key players. This is why healthcare organizations, institutions, and universities around the world are increasing their efforts to involve patients and make their participation active using different forms of engagement [35].

Quality improvement in public health care is a deliberate process because it is not feasible without a clearly defined goal which is annotated through a defined improvement process. [36]. agrees that it's a partnershiporiented process, and during the process, Particular attention and reinforcement is granted to the patients' perspectives, which often match the professionals' concerns. Following the staff and patient perspective interviews and discussions conducted, the following major aspects, including a critical review of health governing boards, administration, technology, specialty expansion via partnership, quality assurance, health funding, were identified. After discussion, deliberation, and the exchange of views, priorities are chosen by consensus and translated into a SMART goal- (Specific, Measurable, Attractive, Realistic, and Timebound) that can be carried out in a speculated time frame. The set of activities should be health-centered and accessible to the health community.

\section{Results/Discussion}

This article proffers a few pertinent perspectives for the scale of priorities.

\section{Critical Review of Health Governing Boards}

There is a continuous informed focus on the need to begin to hold boards of health services accountable for the quality of care obtainable in 
their organizations, especially with the level of cancer health care in Nigeria. As against the perception of a few, the responsibility of improving healthcare delivery is not solely on frontline health officers but rather the main responsibility of the governing board. This view is in tandem with the reports of Goeschel and McSherry R. [37, 38], respectively.

In the course of this paper research, a few senior health professionals at the management level was interviewed on their perceived attitude and the activities of members of the health service boards within their hospitals, and the general reflection was otherwise not pleasant as it is perceived that the boards have no clear, committed plan to improving patients experience following various complaints of non-functioning clinics and non-reviewed infrastructural breakdowns, orchestrated oppression of a specific group of professionals, biased approach implementations on structural distributions and most critically is the unexplainable resistance to overhaul the existing structure and models of care. This finding is very similar to the report of [39]. Active boards must possess proven initiatives that will improve patient experience at the various organizational levels, including cancer health care from the board room to the bedside. These efforts shouldn't be ad-hoc prone as observed in many implementation processes, as it is the direct responsibility of the boards to prioritise and address the delivery of health care to improve cancer patient experience. The attitude and activities of the board members must be understood to be positively impacting the institution's health system based on evidence from a bottom-top approach. These approaches include a positive attitude with highly unbiased and informed decision-based activity.

\section{Administration}

Poor Health Administration in Nigeria has been the bane of the poor health care delivery outcome. According to Sandra's article [40]; our findings suggest that there is much to be gained at the unit level by making sure managers have the knowledge, skills, and abilities to translate human resource-HR policies and practices to empower and to support their staff in the key objective of providing excellent patient care. The compositions of health organizational structures are functions of the multi-disciplinary professionals involved rather than a lobe-sided composition as observed in Nigeria. This is largely a key principle in an ideal health care system. The choice of professional Health administrator in public health institutions is very important in the successful implementation of policies and the achievement of quality improvement in health care. [41, 42, 43]. all noted that in recent years, there had been a growing understanding that organizational culture is related to an organization's performance. Findings make it clear that an organizational response is necessary but not sufficient. However, Sandra and Fowler [40, 44] agree that this requires unit health managers who display transformational leadership via bottom-top management approach, with skills in information sharing, and the ability to encourage teams and decentralized decision making to enhance the empowerment and job satisfaction of their health staff.

\section{Technology}

Modern Health care and technology is fast enhancing health care delivery skills. However, it's one thing to have skills acquisition exercises and access to developmental resources, but it is also important to ensure that proper guidance is given to health care providers with regards to how resources such as internet technology can be harnessed to full capacity. Health employers need this, no matter the level or care. Structural empowerment is related to employee's perceptions of the presence of empowering conditions in the workplace, such as access to information, 
receiving support, resources necessary to do the job, and the opportunity to learn and grow [45]. A few of the needs include alternative stand by an electricity power supply such as inverters at every unit, availability of intra-connected unit telecommunication devices for better workrelated communication at any time, compulsory back-up of infrastructure/instrumentation at all essential units, availability of a fully intraconnected automated paperless system between diagnostic units and other essential clinics, etc.

\section{Specialty Expansion Via Partnership}

It is uncommon to have an institution offer all known clinics/specialties, and even if peradventure it does, not every patient will ultimately utilize the health facilities. Therefore, there is a greater need to balance the investment in the health sector towards a target population (consumer) by engaging the required specialties and clinics. To survive financially, hospitals may need to proactively seek out partners. Most hospitals have extracted as much as they can out of the cost side of the equation. The next step is to play to a bigger patient audience, take on risks, share savings, and reap the benefits of economies of scale. According to Global Hospital \& Healthcare Management, the only way to achieve those goals is to partner with other hospitals or healthcare systems. In Nigeria [46], few hospitals in private partnership health care delivery are beginning to spring up strongly. RFID in Healthcare agrees that for healthcare providers, efficiency is not merely good fiscal practice. It must be a critical component of their mission [47].

\section{Quality Assurance}

The Health Policy Brief noted that adverse events can be due to errors or to negligence, which is the improper, unskilled, or substandard treatment of a patient by a health care professional [48]. She also revealed that preventable medical errors caused an estimated 44,000-98,000 inpatient hospital death per year. The Institute of Medicine also found that
US health care was insufficiently safe, effective, patient-centered, efficient, timely, or equitable (devoid of disparities related to race or ethnicity). This is the most startling of an institute's findings. Considering the above facts, it is important as a government or leadership of any healthcare organization to constantly anticipate various problems before they occur so that there is a sincere corresponding evidential policy put in place to avoid preventable medical errors and errors due to negligence as well as managerial lapses which could cut across all the health care units. A quality management control desk is also important to ensure the 'bottom-up' implementation approach and compliance to Quality improvement.

\section{Health Funding}

While all the aforementioned would serve as a good foundation for health care delivery, however, unequivocal access to health insurance and health facilities at all rural Public Health Centres by all will largely be the true mark of improved health outcomes in Nigeria. This brings to bear on the impact of health insurance over recent years.

According to WHO, much commitment has been shown to achieving universal health coverage (UCH). However, progress has been slow [34]. The 2014 presidential summit declaration affirms that UHC is key to ensuring equitable access to high-quality, affordable health care for all Nigerian [50]. Recent outcomes show that the momentum of its commitment has waned [51]. Less than $15 \%$ of Nigerians have health insurance coverage. Most enrollees are in the formal sector with very poor coverage in the formal sector [50, 52-54]. Apart from Seven states that have indicated interest [50, 52]. Other states, including Lagos, Kwara, Ogun, and Akwa Ibom, are implementing stateled community-based health insurance programs to reach the informal sector with varying levels of coverage and inherent sustainability challenges $[50,55]$. 
According to the National Health Act, 50\% of the basic health care provision fund is managed by the National Health Insurance Scheme to ensure access to a minimum package of health services for all Nigerians and $45 \%$ by the National Primary Healthcare Development Agency for primary health care facility upgrade and maintenance, provision of essential drugs, and development of human resources to primary healthcare facilities. The federal ministry of health manages the remaining 5\% for national health emergencies and response to epidemics [50]. These policies, in my own opinion, are excellent formulas capable of changing the paradigm in a system void of corruption and a lack of sense of leadership.

I agree with numerous excellent public opinions, including [52]. They were of the view that the then government would have to tackle, amongst other issues, tax evasion and inefficient tax collection in other to ensure improved domestic revenue generation. In another article by Abiodun, and Resyst, Lagos tremendously improved internally generated revenues well over $40 \%$ between 2000-2015 $[50,56]$, the revenue has remained steady through to 2020. Lagos had shown an exemplary foot worthy of emulation at the national and subnational levels in Nigeria. Lagos expanded its fiscal space and prioritized its health investment for geriatrics, paediatrics, and youths.

In concurrence with an article by Abiodun and Gupta, The New government in expectation should do the same but by engaging intellectual, economic steps to ensure sufficient funds and also generate substantial fiscal capacity to fund national health reforms by cutting the country's enormous budget for fuel subsidies and reducing the cost of governance in both legislative houses [50, 57]. Sufficient funds can be obtained through sin taxes on products that pose risks to health, such as tobacco and alcohol, progressive levies on phone calls or mobile phone purchases, and taxes on air tickets, foreign exchange transactions, and luxury goods.

Aggressive measures should be sustained in reducing the high cost of re-current expenditures and enforcing a strong stance against corruption by increasing the network reach via training and engaging trained youths through the National youth service corps program. As proposed to the Buhari-led government in 2015, the new government should commit itself to the 2001 Abuja declaration by allocating at least $15 \%$ of its budget to health [58]. According to the World Health Organization, no country has been able to achieve Universal Health Coverage with voluntary health insurance [49]. In alignment with stakeholders, the new government must take health insurance compulsory by facilitating the amendment of the 1999 National Health Insurance Scheme (NHIS) act 35, as also supported by the report of Adebayo in 2015 [59]. In addition, each state should create its health insurance agency with guidance from the NHIS and implement innovative ways to capture the formal and informal sectors. These steps will increase unequivocal access to health insurance by all and will consequently improve our nation's health institutions at all levels.

\section{Conclusion}

I, therefore, recommend that the incoming Minister of Health via the National Health board should consider on the priority list the critical overhaul of the mentioned aspects, including the federal and state hospital boards, Administration, Technology, Specialty Expansion Via Partnerships, Quality Assurance and Health Funding- of the health sector in Nigeria be critically considered and necessary actions should be implemented as well. I am also of the opinion that the delivery of cancer health care would be positively affected consequently if implemented. However, every clinic sub-sector as such has its peculiar challenges. 
According to [36], since the partnership is an oriented process and during the process, particular attention and reinforcement is granted to the patients' perspectives, which often match the professionals' concerns, it is, therefore, crucial to find out in further research, the reality of the challenges within the cancer health care in Nigeria as a sub-sector in the larger perspective of the cancer patients and the essential health workers compared to the physicians.

\section{Acknowledgements}

I wish to thank the Eko Hospital Journal club members, Staffs of the departments of

\section{Reference}

[1] Azubuike, S.O., Muirhead, C., Hayes, L. 2018. Rising global burden of breast cancer: the case of sub-Saharan Africa (with emphasis on Nigeria) and implications for regional development: a review. World J Surg Onc 16, 63 (2018). https://login.research4life.org/tacsgr1doi_org/10.118 6/s12957-018-1345-2.

[2] World Bank 2017 report http://www.worldbank.org/en/country/Nigeria/overv iew. (Accessed on May 10, 2017).

[3] Jabulani Sikhakhane, 2017. African politicians seeking medical help abroad is shameful and harms health care. https://theconversation.com/africanpoliticians-seeking-medical-help-abroad-isshameful-and-harms-health-care-82771. Updated August 25, 2019, 12.40pm Sast.

[4] Seun Opejobi 2021. Buhari'll still travel for routine medical check-ups - Presidency replies to critics. https://dailypost.ng/2021/04/07/buharill-stilltravel-for-routine-medical-checkup-presidencyreplies-critics/. Published on April 7, 2021.

[5] Medical Tourism Association, 2018: http://www.medicaltourism.com/en/facts - Accessed on April 15, 2020.

[6] WHO/WORKFORCEALLIANCE, 2018 http://www.who.int/workforcealliance/nga/en/ (accessed on April 15, 2020).
Oncology Services and Laboratory Services of Eko Hospitals, and Olabisi Onabanjo University Teaching Hospitals. I especially Thank Mrs. Esther A for co-authoring this research with me following the tremendous role played in the data entering, reviewing, and editing of this paper and Kelvin O. for other roles, including manuscript review.

\section{Conflict of interest}

The authors whose names are listed above certify that Henry Aisagbonhi is the lead author, and they have NO conflicts of interest as this article was jointly achieved by all authors.

[7] Human Resource for Health -Country Profile: Nigeria, WHO GHWA, 2008. (Accessed on April 15, 2020).

[8] Binue, V.S, Chandrashekhar, T.S, Subba, S.H. 2007. Cancer pattern in Western Nepal: a hospitalbased retrospective study. Asian Pacific Journal of Cancer Prevention 8, 183-186.

[9] Boyle P., \& Levin, B., World cancer report, Geneva. 2011. International Agency for Research on Cancer. 2011. (Accessed on April 15, 2020).

[10] Olufunsho Awodele, Ayokunle A. Adeyomoye, Demorah F Awodele, Vincet B. Fayankinnu, and Auro C. Dolapo., 2011. Cancer distribution Pattern in south-western Nigeria. Tanzania Journal of Health Research, Volume 13, Number 2, April 2011.

[11]WHO. The Abuja Declaration: ten years on. March 25, 2011. http://www.who.int/healthsystems/publications/abuj a_declaration/en/ (Accessed September 22, 2020).

[12] The Hidden Epidemic, 2016., International Atomic Energy Agency. https://www.iaea.org/newscenter/news/hiddenepidemic. Accessed 7:20 pm, $3^{\text {rd }}$ July 2019. [13]All about cancer, cancer society of Finland www.allaboutcancer.fi/facts-about-cancer/what-iscancerl (accessed May 2020). 
[14]Cancer Research UK- about cancer 2018. www.cancerresearchuk.org.about-cancer (accessed June 2020).

[15] National cancer institute 2012- How cancer is diagnosed. www.cancer.gov/aboutcancer/diagnosis-staging/diagnosis. (Accessed June 2018)

[16] Adebamowo, C.A. \& Ajayi O.O., 2000. Breast cancer in Nigeria. West African Journal Medicine 19, 179-194.

[17] World Health Organization. Cancer Fact SheetFebruary 2017. (Accessed September 22, 2017).

[18] Owoeye I, O, G, and Ibrahim I.A, 2013. Knowledge and attitude towards cervical cancer screening among students and staff in a tertiary institution in the Niger delta. International Journal of Medicine and Biomedical Research. vol 2(1); 4856. January 2013.

[19]Henry Aisagbonhi Osaro and Mgbeafuluba Ifeyinwa. 2018. Constance. Awareness and Practice of Cervical Cancer Screening and Human Papilloma Virus Vaccination (HPV) Uptake among Female Staff in Private Tertiary Hospital in Lagos Nigeria. Texila International Journal of Public Health, Volume 6, Issue 1, Feb 2018.

[20]WHO. Global Health Observatory Data Repository. Nigeria: statistics summary (2002present). http://apps.who.int/gho/data/node.countryNGA (accessed May 20, 2019).

[21] Awodele, Olufunsho, Adeyomoye, Ayokunle, Awodele, Deborah, Fayankinnu, Vincent, Dolapo, Duro. 2011. Cancer distribution pattern in southwestern Nigeria, Tanzania Journal of Health Research

13(2):125-31

DOI:10.4314/thrb.v13i2.55226.

[22] Globocan 2002- estimated cancer incidence and mortality worldwide in 1998 - International agency for research on cancer- WHO. www.globocan.iarc.fr/default.aspx. (Accessed May 2018).

[23] GLOBOCAN 2012- estimated cancer incidence and mortality worldwide in 2012 - International agency for research on cancer- WHO www.globocan.iarc.fr/default.aspx. (Accessed May 2018).
[24]GLOBOCAN, 2008 cancer incidence and mortality worldwide in 2008, - International agency for research on cancer- WHO. www.iarc.fr/en/media-

centre/iarcnews/2010/globocan2008.php. (Accessed May 2018).

[25]American cancer society 2013, https://www.cancer.org/research/cancer-factsstatistics/all-cancer-facts-figures/cancer-factsfigures-2013.html. (Accessed May 2018).

[26]Erdington and MacLean, 2010. https://birminghamresist.wordpress.com/2010/02/26/ erdington-socialists-john-maclean-redclydeside/ (accessed May 2020).

[27]Fatimah Abdulkareem (Prof.), 2011. Epidemiology \& Incidence of Common Cancers in Nigeria. Powerpoint presentation at the Cancer Registries \& Epidemiology workshop April 2011.

[28] Ogundipe, S., \& Obinna, C., 2008. Nigeria: Why cancer is on the rise in the country. RAND blog, 2014. http://www.rand.org/ blog/2014/06/insurance-and-incentives-a-dualapproach-to-try-to.html (accessed May 20, 2015).

[29] Globocan 2003,

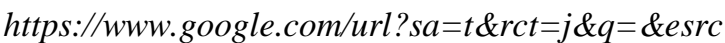
$=s \&$ source $=$ web $\& c d=\& v e d=2$ ahUKEwiH $25 n V u u D$ yAhWrNOwKHbdBApEQFnoECAIQAQ\&url=https $\% 3 \mathrm{~A} \% 2 \mathrm{~F} \% 2 \mathrm{Fgco}$ iarc.fr\%2Ftoday $\% 2 \mathrm{Fdata} \% 2 \mathrm{Fme}$ thods\%2FGLOBOCAN2018_Annex_A.XLSX\&usg= AOvVawOHWJcVJ5-Rz5iYWSuqjwNC. (Accessed May 2020).

[30]WHO (2007a) WHO web site; http://www.who.int/mediacentre/factsheete/fs297/en/ index.html (Accessed May 2018).

[31] WHO (2007b) WHO calls0020for prevention of cancer through healthy workplaces. http://www.who.int/mediacentre/news/notes/2007/np 19/en/index.html (Accessed May 2018).

[32] Federal Republic of Nigeria HRH Strategic Plan 2008-2012. Accessed on June 2018.

[33]Lawal YZ, Samuel EF, Abdul MA, Abdullahi ZG, Rafindadi AL, Faruk JA, et. al., 2017. Nigerian health care: A quick appraisal. Sahel Med J 2017; 20:79-88.

[34]WHO. 2014. World cancer report by. International agency for research on cancer. Editors- 
bernard w. Stewart and Christopher p. Wild. ISBN; 978928320429-9. Cited at www.int/cancer/publications/WRC-2014/en/ (accessed May 2018).

[35] Karazivan P, Dumez V, Flora L, et. al. 2015. The Patient As-Partner Approach in Health Care: A Conceptual Framework for a Necessary Transition. Academic Medicine. Post-Author Corrections: January 20, 2015.

[36] Marie-Pascale Pomey, Hassiba Hihat, May Khalifa, Paule Lebel, André Néron, 2015. Patient partnership in quality improvement of healthcare services: Patients' inputs and challenges faced: patient experience journal, vol2, issue1, article 6, 2015.

[37] Goeschel, CA, Wachter RM, Pronovost PJ., 2010. Responsibility for quality improvement and patient safety: hospital board and medical staff leadership challenges. Chest. 2010; 138(1): 171178.

[38] McSherry R, Pearce P., 2011. Clinical governance: a guide to implementation for healthcare professionals. Malden, MA: WileyBlackwell; 2011.

[39] Bismark marie, 2015, An evidence-based approach to medical regulation 2015, URL: http://www.austlii.edu.au/au/journals/PrecedentAU LA/2015/17.html.

[40] Sandra G. Leggat, Timothy Bartram, Gian Casimir, Pauline Stanton, 2010. Nurse perceptions of the quality of patient care: Confirming the importance of empowerment and job satisfaction Health Care Management Review, OctoberDecember 2010.

[41] Davies, H. T., Mannion, R., Jacobs, R., Powell, A. E., \& Marshall, M. N., 2007. Exploring the relationship between senior management team culture and hospital performance. Medical Care Research and Review, 64(1), 46-65.

[42] Gifford, B. D., Zammuto, R. F., \& Goodman, E. A. 2002. The relationship between hospital unit culture and nurses' quality of work life. Journal of Health Management, 47(1), 13-25.

[43] Scott, T., Mannion, R., Davies, H., \& Marshall, M. 2013. Healthcare performance and organisational culture. United Kingdom: Radcliffe Medical Press Ltd. statistics.html. 2013 report.).

[44]Fowler, Floyd J. Jr., Carrie A. Levin, and Karen R. Sepucha, 2011. "Informing and Involving Patients to Improve the Quality of Medical Decisions," Health Affairs 30, no. 4 (2011): 699706.

[45] Kanter, R. M., 1993. Men and women of the corporation. New York Basic Books. Chapter 4, Pg 32-35.

[46] How Hospitals Can Survive in the New Healthcare Environment 2014. - Global Hospital \& Healthcare Management. http://journals.lww.com/academicmedicine/Abstract/ publishahead/The_Patient_as_Partner_Approach_ $i$ n_Health_Care A.98875.aspx.

[47]RFID in Healthcare, 2015: Reducing Costs and Improving Operational Efficiency. Global Hospital \& Healthcare Management. 2015. Retrieved from http://www.hhmglobal.com/knowledge-bank/technotrends/rfid-in-healthcare-reducing-costs-andimproving-operational-efficiency.

[48] Health Policy Brief: Improving Quality and Safety," Health Affairs, April 15, 2017, retrieved from www.healthaffairs.org/healthpolicybriefs/.

[49] WHO. World health report. Health systems financing - the path to universal coverage. Geneva: World Health Organization, 2010.

[50] Abiodun Awosusi, Temitope Folaranmi, Robert Yates, 2015, Nigeria's new government and public financing for universal health coverage. www.thelancet.com/lancetgh Vol 3 September 2015.

[51] Awosusi A. 2015. Health for All co-hosts national stakeholders meeting on UHC in Nigeria. http://www.msh.org/blog/2014/04/15/health-for-allco-hostsnational-stakeholders-meeting-on-uhc-innigeria (accessed May 20, 2015).

[52] Uzochukwu B, Ughasoro MD, Etiaba E, Okwuosa C, Envuladu E, Onwujekwe OE., 2015. Health care financing in Nigeria: implications for achieving universal health coverage. Niger J Clin Pract 2015; 18: 437-44.

[53] Onoka CA, Kara H, Johanna H., 2014. Towards universal coverage: a policy analysis of the development of the National Health Insurance Scheme in Nigeria. Health Policy Plan 2014; 
published online Oct 21. Doi:10.1093/heapol/ czu116.

[54] Olakunde BO, 2012. Public health care financing in Nigeria: which way forward? Ann Nigerian Med 2012; 6: 4-10.

[55] Okunogbe A., 2014. Insurance and incentives: a dual approach to try to improve maternal health in Nigeria. $\quad$ RAND blog, 2014. http://www.rand.org/blog/2014/06/insurance-andincentives-a-dual-approach-to-try-to.html (accessed May 20, 2015).

[56] Resyst, 2018. Raising domestic resources for health: Can tax revenue help fund Universal Health Coverage? London: Resyst Consortium, (2015. Accessed May 2019).
[57] Gupta V, Dhillon R, Yates R., 2015. Financing universal health coverage by cutting fossil fuel subsidies. Lancet Glob Health 2015; 6: e306-e07.

[58] WHO. Presidential summit on universal health coverage ends in Nigeria. World Health Organization, 2015. http://www.afro.who.int/en/nigeria/pressmaterials/it em/6376-presidential-summit-on-

universalhealthcoverage-ends-in-nigeria.html (accessed September 13, 2017).

[59] Adebayo B. Make health insurance compulsory. Aug 14 , 2013.

http://www.punchng.com/health/make-healthinsurance-compulsory-experts/ (accessed September 12, 2020). 